\title{
Synthesis and secretion of sulphated glycoproteins by rabbit oviduct explants in vitro
}

\author{
B. A. Hyde and D. L. Black \\ Department of Veterinary and Animal Sciences, University of Massachusetts, Amherst, MA 01003, \\ U.S.A.
}

\begin{abstract}
Summary. The ability of rabbit oviduct explants to incorporate radiolabelled precursors into specific secretory products was investigated. Ampullary and isthmic oviduct segments were cultured in the presence of $\left[{ }^{3} \mathrm{H}\right]$ glucosamine or $\left[{ }^{35} \mathrm{~S}\right]$ sodium sulphate. Medium samples were analysed for the presence of secreted, labelled macromolecules.

Explants incorporated the $\left[{ }^{3} \mathrm{H}\right]$ glucosamine and secreted labelled glycoproteins in vitro. SDS gel electrophoresis and subsequent fluorographic analysis of culture medium demonstrated a differential secretion of glycoproteins between the ampulla and the isthmus. Although ampullary tissue secreted a greater amount of labelled glycoproteins during the sampling period, the major secretory constituent of $M_{\mathrm{r}} \sim 66000$ was common to both oviduct segments. Tissue incubated with $\left[{ }^{35}\right.$ S]sodium sulphate also secreted a labelled glycoprotein or subunit of $M_{\mathrm{r}} \sim 66000$.

The results indicate that rabbit oviduct explants are capable of synthesis and secretion of specific sulphated glycoproteins in vitro and that there is a difference in the type and amount of secretion produced between the two oviduct segments.
\end{abstract}

\section{Introduction}

The luminal fluid of the mammalian oviduct, composed of tubal secretions and serum transudate, provides an environment for gamete transport and maturation, fertilization and early embryonic development. There is evidence that oviduct fluid, in addition to providing a favourable environment, may influence embryonic development. It is reasonable to assume, therefore, that oviduct-specific secretions may be necessary for the normal development of embryos in vitro.

It is difficult to study oviduct-specific secretory products in vivo because the ever present serum proteins in oviduct fluid tend to mask their identity. The development of a functional oviduct cell culture system could circumvent this problem by providing a source of newly synthesized secretory products for analysis.

There have been few attempts to culture oviduct cells. Rabbit and pig oviduct epithelial cells have been grown in vitro and characterized morphologically (Nilsson \& Hellstrom, 1957; Hellstrom \& Nilsson, 1957; Bouillant \& Greig, 1973). Bovine oviduct epithelial cells have been cultured and the effects of exogenous gonadotrophic and steroid hormones on the production of lipids, glycogen and enzymic activity determined (Witkowska, 1976, 1979a, b). The ability of rabbit oviduct epithelial cells in suspension to synthesize specific products from radiolabelled precursors has been studied (Barr \& Oliphant, 1981; Oliphant \& Ross, 1982; Oliphant, Reynolds, Smith, Ross \& Marta, 1984). These cultures were maintained for only 4-6h, however, and although synthesis of oviduct-specific glycoproteins was determined, subsequent secretion of these products was not demonstrated.

An oviduct explant culture system provides a means of studying in-vitro secretion from tissue in which the integrity of the epithelial cells is maintained. Such a system also permits observation of 
regional differences in oviduct secretion since explants can be obtained from different portions of the oviduct. Finally, development of this system may provide a technique for subsequent co-culture experiments with early embryos.

\section{Materials}

\section{Materials and Methods}

Animals. Virgin, oestrous Dutch-belted rabbits were individually housed in an environmentally controlled room and received feed and water ad libitum. Animals were isolated for 3 weeks before experimentation to ensure that they were not pseudopregnant.

Collection of oviduct tissue. Animals were killed by an intravenous injection of pentobarbitone sodium into the marginal ear vein. Oviducts were excised aseptically and placed in calcium- and magnesium-free sterile Hank's Balanced Salt Solution (HBSS) with $2 \%$ antibiotic (antibiotic-antimycotic solutions: penicillin base $10000 \mathrm{units} / \mathrm{ml}$, fungizone $25 \mu \mathrm{g} / \mathrm{ml}$, streptomycin base $10000 \mu \mathrm{g} / \mathrm{ml}$; GIBCO, Grand Island, New York, U.S.A.). Tissue from each animal was kept separate so that individual animal variation could be detected. All subsequent procedures were performed in a laminar flow hood.

Oviducts were trimmed of fat, divided at the ampullary-isthmic junction and placed in fresh HBSS. A sample of each oviduct segment was fixed in picric acid-formalin (PAF) for histological examination. Oviducts were opened along the lumen using fine scissors and cut with a razor blade into explants $2-3 \mathrm{~mm}^{2}$. Explants, taken from the ampulla or isthmus, were placed mucosal side up in a $35-\mathrm{mm}$ plastic Petri dish which had been scratched to encourage adherence of the tissue. Four explants were placed in each dish with $0.5 \mathrm{ml}$ of culture medium (explants were not totally immersed). Cultures were incubated in a humidified environment of $5 \% \mathrm{CO}_{2}$ in air at $37^{\circ} \mathrm{C}$.

Culture medium. Two serum-free media were used in this study. NCTC-109 (Gibco) was supplemented with $2 \%$ antibiotic (Gibco antibiotic-antimycotic solution), $25 \mathrm{~mm}-\mathrm{Hepes}$ buffer and one of the following:

(1) insulin $(5 \mu \mathrm{g} / \mathrm{ml})$, transferrin $(5 \mu \mathrm{g} / \mathrm{ml})$ and selenium $(5 \mathrm{ng} / \mathrm{ml})$ (CR-ITS Premix; Collaborative Research, Inc., Lexington, MA, U.S.A.), or

(2) $10^{-5} \mathrm{M}$-hydrocortisone-21 hemisuccinate (Sigma) and $1 \mu \mathrm{g}$ insulin/ml (Sigma, St Louis, MO, U.S.A.).

Culture media were adjusted to $\mathrm{pH} 7 \cdot 2$ with $1 \mathrm{~N}-\mathrm{HCl}$ or $1 \mathrm{~N}-\mathrm{NaOH}$.

\section{Evaluation of culture system}

Assay for release of acid-precipitable, radiolabelled glycoproteins. The method of Adler, Alberghini, Counts \& Auletta (1983) for studying the secretion of mucin by cervical explants was employed. Explants were cultured for $18 \mathrm{~h}$ at $37^{\circ} \mathrm{C}$ in medium containing $6 \mu \mathrm{Ci}$ of a glycoprotein precursor, D-[1,6- $\left.{ }^{3} \mathrm{H}(\mathrm{N})\right]$ glucosamine $\mathrm{HCl}$ (sp. act. $43 \cdot 2 \mathrm{Ci} / \mathrm{mmol}$; New England Nuclear, Boston, MA, U.S.A.). After $18 \mathrm{~h}$ the explants were washed 5 times with HBSS to remove unincorporated label and incubated with $0.5 \mathrm{ml}$ unlabelled medium for $5 \mathrm{~h}$ at $37^{\circ} \mathrm{C}$. After $5 \mathrm{~h}$ the medium was collected and the explants were washed once with medium and incubated for an additional $2 \mathrm{~h}$ in $0.5 \mathrm{ml}$ unlabelled medium. At the end of the $2 \mathrm{~h}$ incubation period the medium was collected and the tissue was washed in HBSS then fixed in PAF.

The initial $5 \mathrm{~h}$ period provided a 'baseline' value to which the 2-h value was compared. By evaluating the dishes on a percentile basis, each dish of explants served as its own control and allowed for comparison between individual dishes. In future experiments, the 2-h period will provide an 'experimental' value after addition of exogenous agents such as hormones (Adler et al., 1983).

Aliquants of the medium removed after the 5-h and 2-h incubation periods were analysed for the presence of secreted, labelled glycoproteins using precipitation by $10 \%$ trichloroacetic acid 
(TCA) plus 0.5\% phosphotungstic acid (PTA) (Adler et al., 1983). To each $0 \cdot 25 \mathrm{ml}$ medium sample, $5 \mathrm{ml}$ cold $\left(4^{\circ} \mathrm{C}\right) 10 \% \mathrm{TCA} / 0.5 \%$ PTA were added and left overnight at $4^{\circ} \mathrm{C}$ to precipitate glycoproteins. The resulting precipitate was washed twice by resuspending in $5 \mathrm{ml}$ fresh, cold TCA/PTA and centrifuging for $10 \mathrm{~min}$ at $500 \mathrm{~g}$. To solubilize the precipitate a method used by Bigsby (1980) was employed. Protosol (New England Nuclear) $(1 \mathrm{ml})$ was added to the pellet and stored overnight at $55^{\circ} \mathrm{C}$. The solubilized sample was cooled and transferred to scintillation vials. Then $0.1 \mathrm{ml} 30 \%$ $\mathrm{H}_{2} \mathrm{O}_{2}$ was added to each vial which was incubated for an additional $30 \mathrm{~min}$ at $55^{\circ} \mathrm{C}$. After cooling, $0.1 \mathrm{ml}$ glacial acetic acid and $10 \mathrm{ml}$ Scinti Verse II (Fisher Scientific, Medford, MA, U.S.A.) were added. Radioactivity in the precipitate was determined using a Searle Delta 300 liquid scintillation counter.

Histochemical analysis. Explants, fixed in PAF, were embedded in paraffin wax and sectioned at 6-7 $\mu \mathrm{m}$. Slides were stained for mucopolysaccharides with Alcian blue, pH 2.5/PAS (AB-PAS) by the method of Jones \& Reid (1973) with one alteration. The 30-min staining with Alcian blue (1\% solution in $0.5 \%$ calcium chloride) was preceded by a 3 min rinse in $3 \%$ acetic acid. Tissue fixed immediately after collection from the animals served as a control.

Gel electrophoresis. Two experiments were performed from which samples were collected for gel electrophoresis. Explant cultures were prepared as described above and pulsed for $18 \mathrm{~h}$ (tissue samples were removed after $1.5 \mathrm{~h}$ for autoradiography) in medium containing CR-ITS Premix and $\left.\left.12 \mu \mathrm{Ci} \mathrm{D}-\left[1,6-{ }^{3} \mathrm{H}\right) \mathrm{N}\right)\right]$ glucosamine $\mathrm{HCl} / \mathrm{ml}$ or $20 \mu \mathrm{Ci}\left[{ }^{35} \mathrm{~S}\right]$ sodium sulphate $/ \mathrm{ml}$ (New England Nuclear). Explants were then washed 5 times with HBSS and incubated with $0.5 \mathrm{ml}$ unlabelled medium for $10 \mathrm{~h}$ at $37^{\circ} \mathrm{C}$. The culture period was extended to $10 \mathrm{~h}$ to increase the amount of radiolabelled secretory products present in the medium, thereby facilitating fluorographic analysis. At the end of the $10-\mathrm{h}$ incubation period the medium was collected for analysis. Tissue samples were fixed in PAF and prepared for autoradiography.

Aliquants of the 10-h media samples were prepared for SDS-gel electrophoresis. Samples were lyophilized and resuspended in $60 \mu \mathrm{l}$ SDS sample buffer (Laemmli, 1970) with the substitution of 40 mm-dithiothreitol (DTT; BIO-RAD, Richmond, CA, U.S.A.) for 2-mercaptoethanol (Hames \& Rickwood, 1984). The samples were evaluated on 8-15\% exponential gradient polyacrylamide slab gels (Laemmli discontinuous buffer system) as described by Van Blerkom (1978). All samples were run concurrently with molecular weight standards (BIO-RAD).

Fluorographic analysis. To detect glycoproteins that had incorporated labelled precursors fluorographic analyses of the polyacrylamide gels were performed (Bonner \& Laskey, 1974). After electrophoresis the gels were fixed and stained with $0 \cdot 1 \%$ Coomassie Blue R-250 in $46 \%$ methanol and $8 \%$ acetic acid for $30 \mathrm{~min}$ and destained overnight in $7 \%$ acetic acid. A platform rocker was used throughout the staining-destaining period. Gels were then transferred to $1 \mathrm{M}$-sodium salicylate (a fluor) for $30 \mathrm{~min}$, dried under heat and vacuum and exposed to Kodak XAR-5 X-ray film ( $\sim 14$ days) at $-70^{\circ} \mathrm{C}$. Exposed film was processed by a Kodak X-OMAT Auto-processor (Kodak, Rochester, NY U.S.A.)

Autoradiography. Histological sections of explants incubated with labelled glucosamine or sodium sulphate were examined by autoradiography (Stein \& Yanishevsky, 1979). Slides were deparaffinized, dipped in a subbing solution $(0.1 \%$ gelatin plus $0.01 \%$ chromium potassium sulphate) and allowed to air dry. They were then dipped $(10 \mathrm{sec})$ in Kodak emulsion NTB-2 (in the dark) and left to dry in an upright position for $1 \mathrm{~h}$. Slides were incubated at $4{ }^{\circ} \mathrm{C}$ (5 days for ${ }^{35} \mathrm{~S}$, 12 days for ${ }^{3} \mathrm{H}$ ) in light-tight boxes containing packets of Drierite (Fisher Scientific). At the appropriate time slides were brought to room temperature, developed in Dektol (Kodak) ( $2 \mathrm{~min}$ ) and acid fixed ( $3 \mathrm{~min}$ ). Tissue was examined after lightly staining with haematoxylin and eosin.

\section{Statistical analysis}

The amount of acid-precipitable glycoproteins secreted into the culture medium was evaluated using a split-plot design (Steel \& Torrie, 1980) and analysed by the Harvey Program (1978). 


\section{Results}

\section{Histochemistry}

Alcian blue, pH 2.5/PAS stained the epithelial cells of all explants from both segments of the oviduct. The supranuclear apical portion of many secretory cells was intensely PAS positive (staining red), indicating the presence of acidic and/or neutral glycoproteins or mucopolysaccharides. Secretory granules which stained blue, an indicator of acidic glycoproteins or mucopolysaccharides, were also found at the apices and most extensively in the crypts of the mucosal folds. A similar staining pattern was observed in control tissue.

The extent of secretory material within cells and the type of staining present between explants and between the control tissue samples was extremely variable. Some cells were bulging with secretion while others appeared thin and contained very little secretory material which appeared as a 'bleb' at the apex.

\section{Assay for release of acid-precipitable, radiolabelled glycoproteins}

The results from the analysis of acid-precipitable glycoproteins are shown in Table 1. The amount of secreted glycoproteins incorporating $\left[{ }^{3} \mathrm{H}\right]$ glucosamine was significantly higher $(P<0.025)$ in medium samples bathing isthmic tissue than ampullary tissue when analysed on a percentile basis with the 5 -h period providing a baseline of secretion. No significant differences were found between individual animals or the two serum-free media tested.

Table 1. Acid-precipitable radiolabelled glycoproteins released into the culture medium after incubation of rabbit oviduct explants for $18 \mathrm{~h}$ with tritiated glucosamine

\begin{tabular}{lccc}
\hline $\begin{array}{l}\text { Tissue } \\
\text { type }\end{array}$ & $\begin{array}{c}\text { c.p.m. over } \\
5 \mathrm{~h} \text { (baseline) }\end{array}$ & $\begin{array}{c}\text { c.p.m. over } \\
2 \mathrm{~h}\end{array}$ & $\begin{array}{c}\% \text { of baseline } \\
(2 \mathrm{~h} / 5 \mathrm{~h})\end{array}$ \\
\hline Ampulla & $12163 \pm 683$ & $3019 \pm 195$ & $25 \cdot 1 \pm 0.088$ \\
Isthmus & $5342 \pm 379$ & $1557 \pm 104$ & $30 \cdot 6 \pm 0.924^{*}$ \\
\hline
\end{tabular}

Values are mean \pm s.e.m. for 24 dishes/4 explants each $/ 12$ animals for ampulla and 23 dishes $/ 4$ explants each $/ 12$ animals for isthmus.

*Statistically significant at $P<0.025$.

\section{Gel electrophoresis}

SDS gel electrophoresis of medium samples collected after the 10-h incubation period demonstrated a major band in the range of $M_{\mathrm{r}} 66000$ while numerous lighter bands were found below this region $\left(M_{\mathrm{r}} 14000-66000\right)$ (Fig. 1). Several small bands of $M_{\mathrm{r}} \sim 92000$ were also present. Media from ampullary tissue incubations consistently produced denser bands on the gels than did media from isthmic cultures, suggesting that the ampullary tissue secreted a greater amount of the specific glycoproteins over the 10 -h sampling period.

\section{Fluorographic analysis}

Differential secretion of glycoproteins between the ampulla and isthmus is demonstrated in Fig. 2. The major band of the polyacrylamide gels $\left(M_{\mathrm{r}} \sim 66000\right.$, shown in Fig. 1) was also the major radiolabelled band to appear on the fluorographs. As on the gels, the band was more dense in samples from ampullary cultures than in those from isthmic cultures. Secretory differences between 


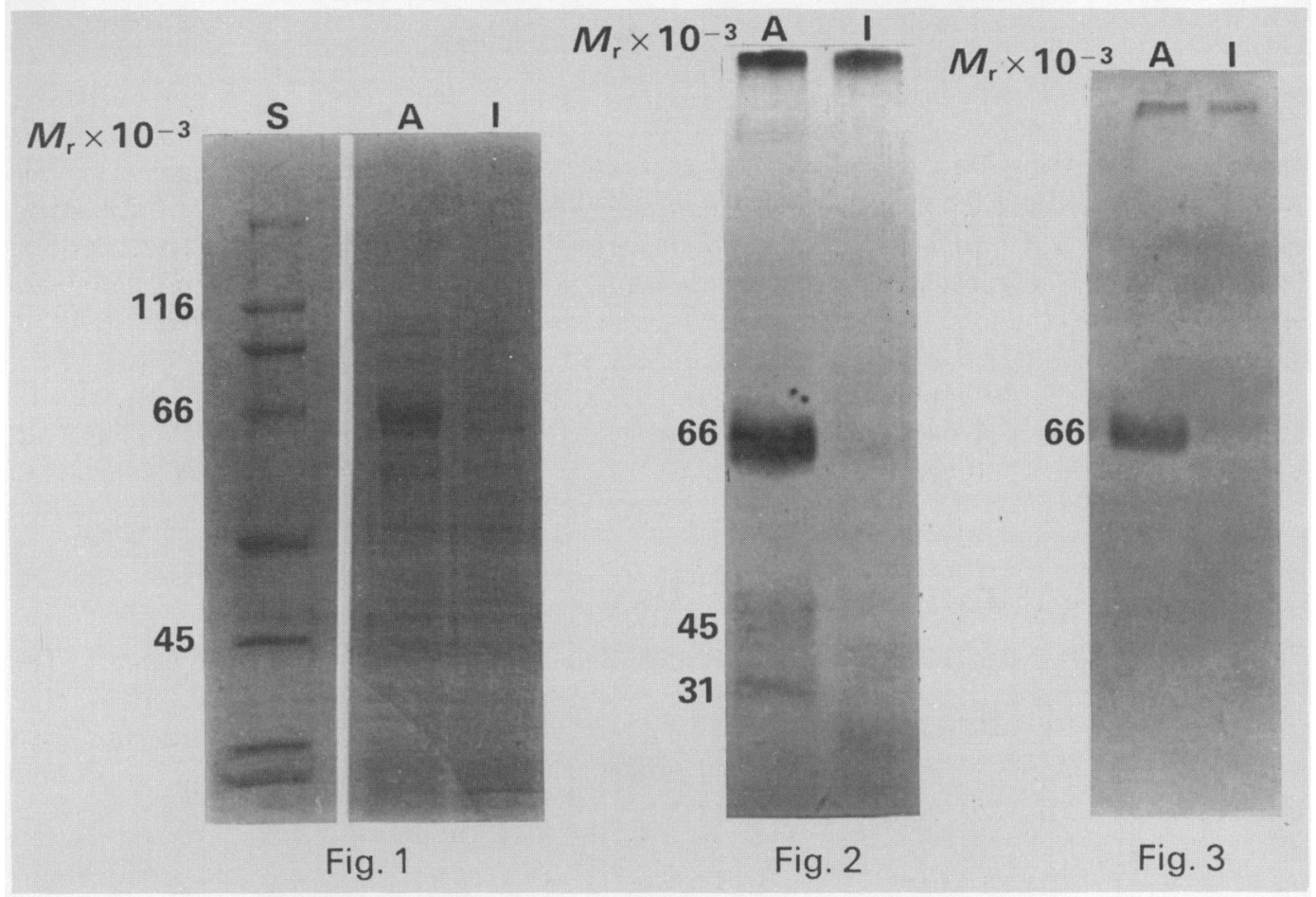

Fig. 1. SDS polyacrylamide gel electrophoresis of medium samples collected after 10-h incubation with explants of ampulla (A) or isthmus (I). Molecular weight standards (S) were run concurrently. Numerous bands are present throughout the range of the standards with a major band of $M_{\mathrm{r}} \sim 66000$ being most dense in the ampullary sample.

Fig. 2. Fluorograph of secreted proteins present in explant culture media after 18 -h incubation with $\left[{ }^{3} \mathrm{H}\right]$ glucosamine and a subsequent 10 -h label-free culture period. A differential secretion is evident between ampullary (A) and isthmic (I) explants, with the more dense band occurring in the ampullary sample at $M_{\mathrm{r}} \sim 66000$. Labelled material at the top of the lanes indicates a large component(s) that was not dissociated by the SDS treatment.

Fig. 3. Fluorograph of secreted proteins present in explant culture media after 18 -h incubation with $\left[{ }^{35}\right.$ S]sodium sulphate and a subsequent 10 -h label-free culture period. A labelled band is present at $M_{\mathrm{r}} \sim 66000$, being most dense in the ampullary sample. Labelled material at the top of the lanes indicates a large component(s) that was not dissociated by the SDS treatment.

the two segments were also evident in the banding pattern of lower molecular weight products. Ampullary medium samples contained labelled glycoproteins in the range of $M_{\mathrm{r}} 45000-32000$. Isthmic samples, while containing low amounts of these secretory products, also contained labelled glycoproteins of molecular weight $<31000$. Some labelled material remained at the top of the fluorograph, indicating the presence of a large component(s) that was not dissociated by SDS treatment.

The second fluorograph (Fig. 3) indicates which of the secreted glycoproteins were sulphated. The sulphated bands were not as dense as in the previous fluorograph, but a main labelled band in the region of $M_{\mathrm{r}} 66000$ was present. This band was generally more dense in ampullary than in isthmic samples. Labelled material remained at the top of the fluorograph, indicating a large component(s) which was not dissociated. 

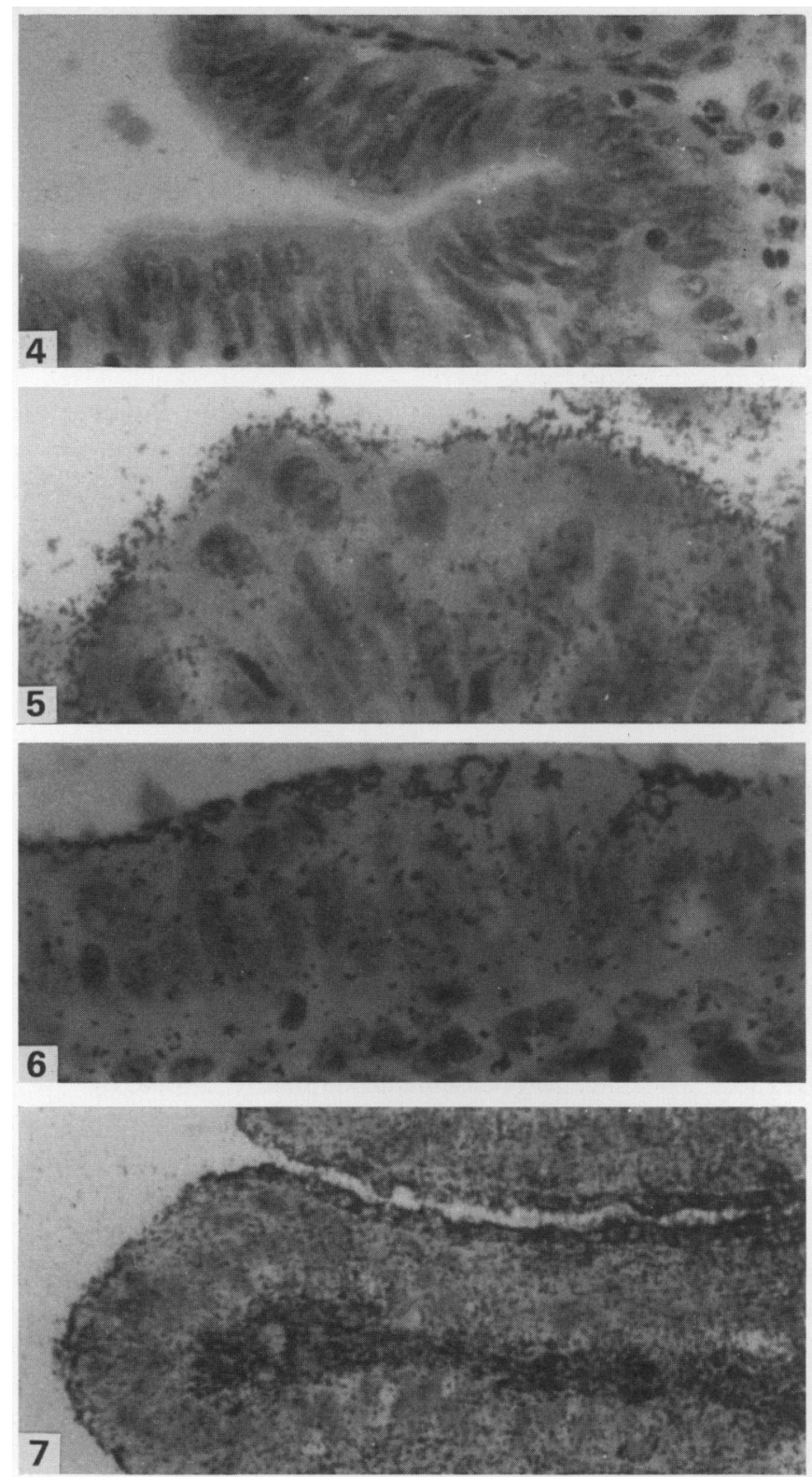

Fig. 4. Autoradiograph of oviduct explant after short-term $(1 \cdot 5 \mathrm{~h})$ exposure to $\left[{ }^{35}\right.$ S]sodium sulphate. The number of silver granules over the tissue is no higher than background. $\times 397$.

Fig. 5. Autoradiograph of oviduct explant after long-term $(30 \mathrm{~h})$ exposure to $\left[{ }^{35} \mathrm{~S}\right]$ sodium sulphate. Most of the granules are concentrated at the apical border of the epithelial cells and within the connective tissue of the mucosal folds. $\times 833$.

Fig. 6. Autoradiograph of oviduct explant after short-term $(1.5 \mathrm{~h})$ exposure to $\left[{ }^{3} \mathrm{H}\right]$ glucosamine. Granules are beginning to concentrate along the apical border of the epithelial cells. $\times 867$.

Fig. 7. Autoradiograph of oviduct explant after long-term $(30 \mathrm{~h})$ exposure to $\left[{ }^{3} \mathrm{H}\right] \mathrm{glucosamine}$. Silver granules are highly concentrated along the apical border of the epithelial cells and in the underlying connective tissue of the mucosal folds. $\times 414$. 


\section{Autoradiography}

Slides were assessed after short-term $(1.5 \mathrm{~h})$ and long-term $(30 \mathrm{~h})$ exposure to $\left[{ }^{3} \mathrm{H}\right]$ glucosamine or $\left[{ }^{35} \mathrm{~S}\right]$ sulphate. Silver grains were an indication of underlying radioactive material. After shortterm exposure to $\left[{ }^{35} \mathrm{~S}\right]$ sulphate (Fig. 4 ) the number of silver granules over the tissue was no higher than background. After $30 \mathrm{~h}$ (Fig. 5), most of the granules were concentrated at the apical border of the epithelial cells and within the connective tissue of the mucosal folds. Granules were often found inside the epithelial cells themselves although this observation was not consistent. Few granules were present in the deeper connective tissue layer.

Autoradiographs of tissue from explants exposed to $\left[{ }^{3} \mathrm{H}\right]$ glucosamine during the short-term period revealed few granules although there were areas where granules were beginning to concentrate along the apical border (Fig. 6). Radiation in the tissue after $30 \mathrm{~h}$ exposure to $\left[{ }^{3} \mathrm{H}\right]$ glucosamine (Fig. 7) was much greater than in tissue exposed to $\left[{ }^{35} \mathrm{~S}\right]$ sulphate. Granules were highly concentrated along the apical border of the epithelial cells and in the underlying connective tissue of the mucosal folds. Granules also were present within the epithelial cells themselves but not as heavily concentrated as in the areas previously mentioned.

\section{Discussion}

Preliminary experiments in our laboratory have demonstrated that culture medium NCTC-109 (Gibco), when supplemented with $10 \%$ fetal bovine serum, supports growth and proliferaton of oviduct epithelial cells in culture (D. L. Black, unpublished). Although serum is routinely added to culture media to provide compounds necessary for growth and development of cultured cells (Barnes \& Sato, 1980a), studies concerning the release of cellular secretory products in vitro are easier to interpret in the absence of serum proteins. Two serum-free media were utilized in this study, each containing several compounds known to stimulate growth and development of numerous cell lines in the absence of serum (McKeehan, Hamilton \& Ham, 1976; Ham \& McKeehan, 1978; Hayashi, Larner \& Sato, 1978; Barnes \& Sato, 1980a, b).

Histochemical analysis was the first step taken to evaluate the oviduct explants for the presence of secretory material. The results presented here are in agreement with those of Oliphant et al. (1984) and demonstrate that explants isolated from both segments of the oviduct contain secretory material which stains with Alcian blue for acidic glycoproteins or mucopolysaccharides. This, however, is contrary to the observations of Jansen \& Bajpai (1982) who suggested that Alcian blue-positive material was confined to the isthmus. The presence of PAS-positive material in the apical portions of many of the secretory cells also was observed by Brower \& Anderson (1969) and Jansen \& Bajpai (1982). Since PAS will stain both neutral and acidic glycoproteins it is not possible to ascertain from these observations whether the AB/PAS staining represents two different secretory products or simply one.

While the histological sections indicate the presence of secretory material, they do not differentiate between secretory material present at the time of tissue collection and that which may be newly synthesized by the cells in vitro. The pertinent question is, are the secretory cells capable of an active secretory function when placed in a culture system?

Explant culture medium was assayed for the presence of radiolabelled glycoproteins. Because of the wide variation in absolute c.p.m. in both the 5 -h and 2-h precipitates it was necessary to use a baseline measurement of secretion to compare values obtained between dishes (Adler et al., 1983). Although the medium bathing ampullary tissue contained consistently higher counts than media bathing isthmic tissue for the individual time periods, the isthmic tissue demonstrated a significantly higher percentage of baseline secretion (2-h c.p.m./5-h c.p.m.) (Table 1). Since the c.p.m. in the $2-h$ sample were closer to those recorded for the initial $5-h$ period, the value expressed as a percentage was higher for the isthmic tissue than for the ampullary tissue. This indicates that the isthmic tissue secretes specific glycoproteins more consistently throughout the 7 -h sampling period. 
The labelled glycoproteins present in the medium samples were further analysed through the use of electrophoretic and fluorographic techniques. The major band on the SDS-polyacrylamide gels and subsequent fluorographs represents a glycoprotein or subunit with a molecular weight of $\sim 66000$. Several studies report the presence of a major sulphated component in rabbit oviduct fluid with a molecular weight of 72000-73000 (Shapiro, Jentsch \& Yard, 1974; Hanscom \& Oliphant, 1976). Others have demonstrated oviduct specific subunits in this molecular weight range from $\left[{ }^{35}\right.$ S $]$ sulphate-labelled extracts of cultured oviducal epithelium (Barr \& Oliphant, 1981; Oliphant \& Ross, 1982; Oliphant et al., 1984). Although the major labelled component isolated from the oviduct explant media may be slightly smaller in size than that found in previous work, the similarity in the molecular weight range does indicate the need for further analysis of this system. The appearance of other bands both on the gels and fluorographs indicates the presence of lower molecular weight proteins or subunits and further demonstrates differential secretion between the ampulla and the isthmus.

Autoradiographic analysis of the explants after exposure to $\left[{ }^{3} \mathrm{H}\right]$ glucosamine or $\left[{ }^{35} \mathrm{~S}\right] \mathrm{sulphate}$ demonstrated the localization of these labelled precursors within the tissue. Radioactivity was more extensive in explants exposed to $\left[{ }^{3} \mathrm{H}\right]$ glucosamine than in those exposed to $\left[{ }^{35} \mathrm{~S}\right]$ sulphate. Oliphant et al. (1984) have demonstrated that exposure to oestrogen is necessary for the incorporation of sulphate and leucine into specific glycoproteins by oviduct cells, while fetal bovine serum albumin was found to increase incorporation of $\left[{ }^{35} \mathrm{~S}\right]$ sulphate into secreted mucin glycoproteins by tracheal explants (Lloyd, Kennedy \& Mendicino, 1984). The lack of serum proteins or hormone replacement in the culture medium may be the cause of lower sulphate incorporation by the oviduct explants in this study.

The results of this study indicate that rabbit oviduct explants are capable of synthesis and secretion of specific sulphated glycoproteins in vitro and that there is a difference in the type and amount of secretion produced between the two oviduct segments. Since this explant culture system mimics oviduct function in vitro, it may prove useful in co-culture experiments with early embryos by providing a 'temporary incubator' for those embryos destined for transfer.

We thank Melinda L. Boice and Dr Eric Overström for helpful discussion throughout this study.

\section{References}

Adler, K.B., Alberghini, T.V., Counts, D.F. \& Auletta, F.J. (1983) Secretion of mucin by explants of rabbit and human cervix in organ culture. Biol. Reprod. 29, $751-765$.

Barnes, D. \& Sato, G. (1980a) Methods for growth of cultured cells in serum-free medium. Analyt. Biochem. 102, 255-270.

Barnes, D. \& Sato, G. (1980b) Serum-free cell culture: a unifying approach. Cell 22, 649-655.

Barr, S. \& Oliphant, G. (1981) Sulfate incorporation into macromolecules produced by cultured oviductal epithelium. Biol. Reprod. 24, 852-858.

Bigsby, R.M. (1980) The role of estrogen in control of ovum transport: a comparative study using passive immunization against estradiol-17 $\beta$ in mice and rabbits. Ph.D. thesis, University of Massachusetts.

Bonner, W.M. \& Laskey, R.A. (1974) A film detection method for tritium-labelled proteins and nucleic acids in polyacrylamide gels. Eur. J. Biochem. 46, 83-85.
Bouillant, A. \& Greig, A.S. (1973) Biological characterization of a cell line derived from the pig oviduct. In Vitro 9, 92-102.

Brower, L.K. \& Anderson, E. (1969) Cytological events associated with the secretory process in the rabbit oviduct. Biol. Reprod. 1, 130-148.

Ham, R.G. \& McKeehan, W.L. (1978) Development of improved media and culture conditions for clonal growth of normal diploid cells. In Vitro 14, 11-22.

Hames, B.D. \& Rickwood, D. (1984) Gel Electrophoresis of Proteins-A Practical Approach, IRL Press, Oxford.

Hanscom, D. \& Oliphant, G. (1976) Hormonal regulation of incorporation of ${ }^{35} \mathrm{~S}$ into macromolecules of oviduct fluid. Biol. Reprod. 14, 599-604.

Harvey, W.R. (1978) User's guide for LSML78. The Ohio State University, Columbus.

Hayashi, I., Larner, J. \& Sato, G. (1978) Hormonal growth control of cells in culture. In Vitro 14, 23-30.

Hellstrom, K.E. \& Nilsson, O. (1957) In vitro investi- 
gation of the ciliated and secretory cells in the rabbit fallopian tube. Expl Cell Res. 12, 180-201.

Jansen, R.P.S. \& Bajpai, V.K. (1982) Ovidust acid mucus glycoproteins in the estrous rabbit: ultrastructure and histochemistry. Biol. Reprod. 26, 155-168.

Jones, R. \& Reid, L. (1973) The effect of $\mathrm{pH}$ on Alcian blue staining of epithelial acid glycoproteins. I. Sialomucins and sulphomucins (singly or in simple combinations). Histochem. J. 5, 9-18.

Laemmli, U.K. (1970) Cleavage of structural proteins during the assembly of the head of bacteriophage T4. Nature, Lond. 227, 680-685.

Lloyd, C., Kennedy, J.R. \& Mendicino, J. (1984) Regulation of the synthesis of mucin glycoproteins in swine trachea explants. In Vitro 20, $416-432$.

McKeehan, W.L., Hamilton, W.G. \& Ham, R.G. (1976) Selenium is an essential trace nutrient for growth of WI-38 diploid human fibroblasts. Proc. natn. Acad. Sci. U.S.A. 73, 2023-2027.

Nilsson, O. \& Hellstrom, K. (1957) Cell types identified in tissue cultures of epithelium of the rabbit fallopian tube. Acta obstet. gynaec. scand. 36, 340-346.

Oliphant, G. \& Ross, P.R. (1982) Demonstration of production and isolation of three sulphated glycoproteins from the rabbit oviduct. Biol. Reprod. 26, $537-544$.

Oliphant, G., Reynolds, A.B., Smith, P.F., Ross, P.R. \& Marta, J.S. (1984) Immunocytochemical localization and determination of hormone-induced synthesis of the sulfated oviductal glycoproteins. Biol. Reprod. 31, 165-174.
Shapiro, S.S., Jentsch, J. \& Yard, A.S. (1974) Isolation of an acidic glycoprotein from rabbit oviductal fluid and its association with the egg coating. $J$. Reprod. Fert. 40, 281-290.

Steel, R.G.D. \& Torrie, J.H. (1980) Principles and Procedures of Statistics, McGraw-Hill Book Co., New York.

Stein, G. \& Yanishevksy, R. (1979) Autoradiography. In Methods in Enzymology, vol. 58: Cell Culture, pp. 279-292. Eds W. B. Jakoby \& J. H. Pastan. Academic Press, Inc. New York.

Van Blerkom, J. (1978) Methods for the high-resolution analysis of protein synthesis: applications to studies of early mammalian development. In Methods in Mammalian Reproduction, pp. 67-109. Ed. J. C. Daniel, Jr. Academic Press, New York.

Witkowska, E. (1976) Tissue culture of isolated epithelial cells of the bovine oviduct. Bull. Acad. pol. Sci. Cl. II Sér. Sci biol. 24, 373-376.

Witkowska, E. (1979a) Reactivity of the epithelial cells of the bovine oviduct in vitro on the exogenic gonadotropic and steroid hormones. I. The effect of gonadotropic and steroid hormones on the amount of lipids and activity of dehydrogenases. Folia Histochem. Cytochem. 17, 225-238.

Witkowska, E. (1979b) Reactivity of the epithelial cells of the bovine oviduct in vitro on the exogenic gonadotropic and steroid hormones. III. The effect of gonadotropic hormones on the amount of glycogen and of acid and alkaline phosphatases. Folia Histochem. Cytochem. 17, 239-250.

Received 27 November 1985 